\title{
THE DEVELOPMENT OF THE UNIQUE MODEL OF WOMEN'S JUMPSUITS USING 2D/3DCAD SYSTEM OF THE CLOTHES CONSTRUCTION
}

Sladjana S. Antić*, Ana B. Ilić, Dragana V. Radosavljević, Svetomir Z. Golubović

(PROFESSIONAL PAPER) UDC 687.12:677.011

High Vocational School for Textiles, Leskovac, Serbia

Modern computer systems solve a number of problems encountered nowadays by clothes manufacturers, such as a frequent change of models in accordance with fashion seasons and the requirements for a quick access to the market. In this paper, on the basis of the basic construction of women's jumpsuit (overalls), modeling, as well as the complete manufacturing procedure of $2 \mathrm{D}$ cut was performed by the application of 2D/3D CAD system of the clothes construction. Virtual simulation was performed on the basis of the selected textile fabric taking into consideration the design and the properties of the fabric. All necessary parameters for simulation realization were defined and the analysis of the results verified the modeled cuts.
Keywords: basic construction, modeling, $2 \mathrm{D}$ cuts and $3 \mathrm{D}$ simulation

\section{Introduction}

The conception of modern computer systems is based on the flexible production of garments using new technologies. As well as in others, in clothing manufacture computers, as well as additional input-output units, became a very important factor which simplifies, speeds up and allows more precise work. The application of the Geber Technology system covers a part of the procedures by segments of the basic construction and modeling in PDS and 3D simulation of clothing in V-Stitcher. [1,2]. The order of completing the operations is precised.

The basic construction of women's jumpsuit in pds

The construction of the basic cut is drown for the elected garment and it represents schemes with auxiliary and main construction lines on which the garment or its part is projected. [3] Decomposition parts are taken from the basic cut and their modeling is then performed. Modeling is done in order to obtain new 2D forms of decomposition parts which better adjust to the lineament, design model and material from which the model is made. A design model of the women's jumpsuit is shown in Figure 1.

Description of the model:

A front part of the jumpsuit consists of two parts, backside also consists of two parts with the zipper on the line of the back's middle. An accentuated waist is characteristic and the bottom of the trousers with the emphasis on the expansion from the knee to the length, with the total length of $40 \mathrm{~cm}$.

\footnotetext{
* Author address: Sladjana Antić, High Vocational School for Textiles, 16000 Leskovac, Vilema Pušmana 17, Serbia

E-mail: sladjaantic@hotmail.com

The manuscript received: March, 13, 2015.

Paper accepted: August, 05, 2015
}

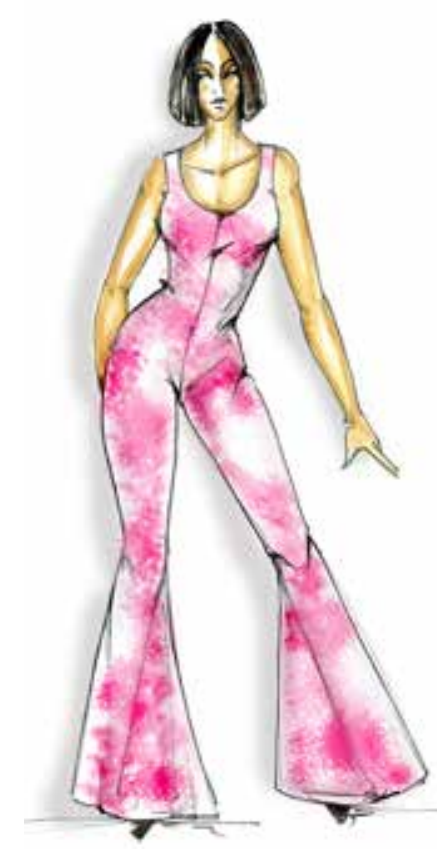

Figure 1. Women's suit model design

For the basic construction of the women's jumpsuit SRPS ISO/TR 10652 standard was used.

Size $84 \mathrm{MR}$

Main measures:

$\begin{array}{lllllc}\text { Vt Height } & & & 1 / 2 & 1 / 4 & 1 / 8 \\ \text { Og Chest circumference } & = & 168 \mathrm{~cm} & 84 & 42,0 & 21,0 \\ \text { Os Waist circumference } & = & 66 \mathrm{~cm} & 42 & 21,0 & 10,5 \\ \text { Ob Hips circumference } & = & 90 \mathrm{~cm} & 43 & 16,5 & -\end{array}$


Constructional measures:

\begin{tabular}{lllr} 
Svi - Neckline width & $=1 / 20 \mathrm{Og}+2 \mathrm{~cm}$ & $=6,2 \mathrm{~cm}$ \\
Dri - Depth of sleeves neckline & $=1 / 10 \mathrm{Og}+10,5 \mathrm{~cm}+1 \mathrm{~cm}$ & $=19,9 \mathrm{~cm}$ \\
$\mathrm{DI}-$ Back length & $=1 / 4 \mathrm{Vt}-1 \mathrm{~cm}$ & $=41,0 \mathrm{~cm}$ \\
$\mathrm{Dm}-$ Model length & $=\mathrm{DI}$ & $=41,0 \mathrm{~cm}$ \\
$\mathrm{Pd}-$ Front length & $=\mathrm{DI}+1 / 20 \mathrm{Og}-0,5 \mathrm{~cm}$ & $=44,7 \mathrm{~cm}$ \\
$\mathrm{SI}-$ Back width & $=1 / 8 \mathrm{Og}+5,5 \mathrm{~cm}$ & $=16,0 \mathrm{~cm}$ \\
\hline $\mathrm{Sri}-$ Width of sleeves neckline & $=1 / 8 \mathrm{Og}-1,5 \mathrm{~cm}$ & $=9,0 \mathrm{~cm}$ \\
$\mathrm{Sg}-$ Chest width & $=2 / 8 \mathrm{Og}-4 \mathrm{~cm}$ & $=17,0 \mathrm{~cm}$ \\
& $=1 / 2 \mathrm{gg}$ & $=42,0 \mathrm{~cm}$ \\
\hline $\mathrm{Sg}-$ Chest depth & $=1 / 4 \mathrm{Og}+5 \mathrm{~cm}$ & $=26,0 \mathrm{~cm}$
\end{tabular}

Depending on the garment, model, material or mode, on most of the main measures the addition for comfortable wearing which can be smaller or bigger is added. The basic construction of the blouse is drawn without additions for comfort wearing because it is made from materials with elastin. [4]

The description of the basic construction of the women's blouse

Based on the measures (main and constructional), using specific tools and functions which can be find in the tool or mini bar on the desktop of PDS shown as icons (I), the basic construction is made. [5]

The basic construction of the blouse is shown in Figure 2.

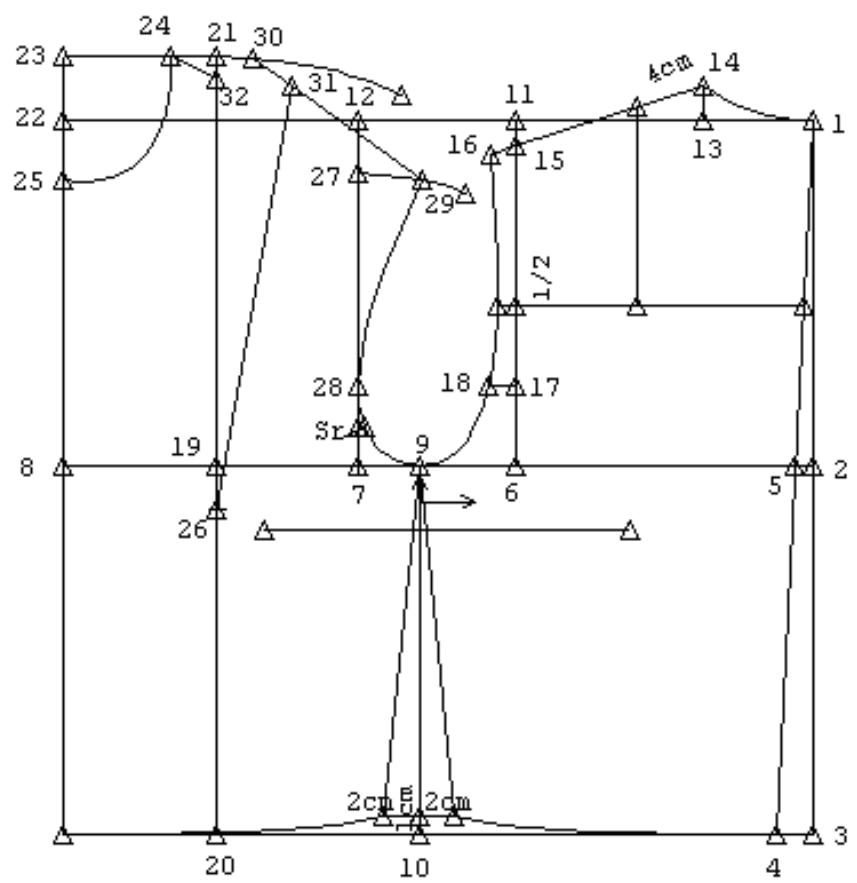

Figure 2. Women's blouse basic construction

1- I. Rectangle $\mathrm{x}=42 \mathrm{~cm}(1 / 2 \mathrm{Og}), \mathrm{y}=41 \mathrm{~cm}(\mathrm{Dm})$ Name of a tailoring part: 1-OK-BLOUSE

1 to $2=19,9 \mathrm{~cm}$ (Dri), I. Copy offset - no offset $=1$, chest line is to be drawn;

1 to $3=41 \mathrm{~cm}(\mathrm{y}=\mathrm{Dm})$;

3 to $4=2 \mathrm{~cm}$, I. Split the line;

1 to $4=I$. 2 point line, dots 1 and 4 are going to be connected;
2 to $5=I$. Distance $2 \mathrm{pt} /$ Measure Straight, measure the distance between dots 2 and 5 ;

5 - I. Split the line, in dot 5 ;

5 to $6=16 \mathrm{~cm}(\mathrm{SI})$, I. Split the line

6 - I. Per on line- half, on the line of chest from dot 6 we're drawing the line across the line of the neckline;

- I. Clipping, cut the excess lines across the neckline

6 to $7=9 \mathrm{~cm}$ (Sri) I. Split the line;

7 - I. Per on line- half, on the line of the chest from dot 7 a line is drawn across the line of the neckline;

7 to 8 - I. Line length, measuring the distance between the dots for verification;

7 to $9=1 / 3$ Sri $+0,5=3,5 \mathrm{~cm}, I$. Split the line;

$9-I$. Per on line- half, on the line of the chest across the length line a line is drawn;

$10-$ I. Clipping, cut the excess line across the length line; 1 to $13=6,2 \mathrm{~cm}$ (Svi), I. Per on line - beginning $=6,2 \mathrm{~cm}$, distance $=2 \mathrm{~cm}(2 \mathrm{~cm}$ represents the distance between 13 and 14 dots);

1 to $14-l$. 2 point curve, the dots are connected and the neckline back curve is shaped;

11 to $15=1,5 \mathrm{~cm}$, I. Split the line;

14 to $15-$ I. 2 point line, dots are connected with the straight line;

15 to $16=1,5 \mathrm{~cm}, I .2$ point line, draws a line in overtime for $1.5 \mathrm{~cm}$;

6 to $17=4,6 \mathrm{~cm}$ (1/4 from 6 to 15), I. Per on line - distance $=4,6 \mathrm{~cm}$, distance $=1,5 \mathrm{~cm}(1,5 \mathrm{~cm}$ is the distance from dot 17 to 18 );

16 to $9-$ I. 2 point curve, connects the dots and shapes the curve of the sleeves back part;

8 to $19=8,9 \mathrm{~cm}(1 / 10 \mathrm{Og}+0.5 \mathrm{~cm})$, I. Split the line;

19 - I. Per on line - whole, draws the line across the neckline and the length line; I. Clipping, cut the excess lines across the length line

20 to $21=44,7 \mathrm{~cm}(\mathrm{Pd})$, I. Split the line;

- I. Delete the line, deletes the excess line;

- I. Per on line, draws the line from dot 21 to right across the middle line;

- I. Per on line, draws the line from dot 22 vertically up till intersection with the line from dot 21 ;

- I. Clipping, cut excess line;

23 to $24=6,2 \mathrm{~cm}$ (Svi), I. Split the line;

23 to $25=7,2 \mathrm{~cm}(\mathrm{Svi}+1 \mathrm{~cm}), \mathrm{I}$. Split the line;

24 to $25-$ I. 2 point curve, connect the dots and shapes the curve of the front neckline part

21 to $26-26 \mathrm{~cm}(\mathrm{Dg})$, I. Split the line;

7 to $27=16,9 \mathrm{~cm}$ (measure the distance from the back part to dots 6 to $15-1,5 \mathrm{~cm})$, I. Split the line;

7 to $28=4,6 \mathrm{~cm}$ (distance from 6 to 17 from the back part), I. Split the line;

7 to $\mathrm{Sr}=2,25 \mathrm{~cm}$ (1/4 Sri), I. Split the line;

7 - Centre in dot $7-$ and Circle with a radius $=16.9 \mathrm{~cm}$ (distance from 7 to 27 );

27 - I. Split the line, cuts the circle line in dot 27 and about $7 \mathrm{~cm}$ right;

26 - Centre in dot 26 - and Circle with a radius $=26 \mathrm{~cm}$ (distance from 26 to 21); 
21 - I. Split the line; , cut the circle line in dot 21 and at the distance of $14 \mathrm{~cm}$ right;

27 to $29=3,7 \mathrm{~cm}(1 / 20 \mathrm{Og}-0.5 \mathrm{~cm})$, I. Split the line;

29 to $9-$ I. 2 point curve, connect the dots and shape a sleeve's front part;

29 to $30=11,94 \mathrm{~cm}$ (measure the back part line from dot 14 to $16-0.5 \mathrm{~cm}$ ), I. 2 point line;

30 to $31=2,70 \mathrm{~cm}$ (transmit the measured distance from dot 24 to 21), I. Split the line;

31 to $26-$ I. 2 point line, connect the dots;

26 to $32=$ Transmits the measured distance from dot 26

to 31, I. Split the line $=24,59 \mathrm{~cm}$

24 to $32-$ I. 2 point line, connect the dots;

10 - Measure $1 \mathrm{~cm}$ up from dot $10, I$. Split the line;

- I. Per on line - whole, from dot 10 , distance $=4 \mathrm{~cm}$;

- I. 2 point line, connect the dots on side seems with $\operatorname{dot} 9$;

- I. 2 point curve, connect the dots and shape the curve on the length;

- $1 / 2$ (from 16 to 15$)=9,2 \mathrm{~cm}$ l. Per on line-whole, line is drawn across the line of the sleeve curvature;

- I. Clipping, cut the line excess;

$14=4 \mathrm{~cm}, I .2$ point line - distance $=4 \mathrm{~cm}, \mathrm{x}=0, \mathrm{y}=12 \mathrm{~cm}$

- I. Clipping, cut the line excess;

- I. Add notch, notches are added in the sleeves on dots $\mathrm{Sr}$ and 18;

The separation of tailoring parts of the women's blouse

Tailoring parts are being separated from the construction base with the tool I. Draft. The name of decomposition parts: 1-BL-PD and 1-BL-ZD. The gusset on the back part is opened with tool I. Add the gusset (Figure 3 ).


Figure 3. Women's blouse tailoring parts

The basic construction of women's pants

For the construction of women's pants of the given size the following measures are needed.

\begin{tabular}{|c|c|c|c|c|c|c|}
\hline \multicolumn{4}{|c|}{ Main measures - size 36} & $1 / 2$ & $1 / 4$ & $1 / 8$ \\
\hline Vt & Height & $=$ & $168 \mathrm{~cm}$ & 84 & 42,0 & 21,0 \\
\hline Os & Waist circumference & $=$ & $66 \mathrm{~cm}$ & 33 & 16,5 & - \\
\hline $\mathrm{Ob}$ & Hips circumference & $=$ & $90 \mathrm{~cm}$ & 47 & 23,5 & - \\
\hline
\end{tabular}

\section{Constructional measures:}

$\begin{array}{lll}\mathrm{Dp} & - & \text { Pants length } \\ \mathrm{Ds} & - & \text { Saddles depth } \\ \mathrm{Vb} & - & \text { Hips height } \\ \mathrm{Spn} & - & \text { Front trouser width } \\ \mathrm{Szn} & - & \text { Back trouser width } \\ \text { Ond } & - & \text { Trouser length volume } \\ \mathrm{Dk} & - & \text { Stride length }\end{array}$

\begin{tabular}{|c|c|c|}
\hline $5 / 8 \mathrm{Vt}-0,5 \mathrm{~cm}$ & $=$ & $104,5 \mathrm{~cm}$ \\
\hline $1 / 4 \mathrm{Ob}+2$ to $3 \mathrm{~cm}$ & $=$ & $24,5 \mathrm{~cm}$ \\
\hline $1 / 20 O b+3 c m$ & $=$ & $7,5 \mathrm{~cm}$ \\
\hline $1 / 4 O b-1 c m$ & $=$ & $21,5 \mathrm{~cm}$ \\
\hline $1 / 4 O b+1 c m$ & $=$ & $23,5 \mathrm{~cm}$ \\
\hline Adopted measure & $=$ & $38,0 \mathrm{~cm}$ \\
\hline $\begin{array}{l}\text { Dp - Ds, or } \\
4 / 8 \mathrm{Vt}-3 \mathrm{~cm}\end{array}$ & $=$ & $81,0 \mathrm{~cm}$ \\
\hline
\end{tabular}

The description of the basic construction of front and back parts of women's pants

The basic construction of the front part of women's pants is shown in Figure 4. The description of the front part of the pants

1 to $2-I$. Rectangle $\mathrm{x}=32 \mathrm{~cm}$, $(S p n+10.5 \mathrm{~cm}$ space for the saddle width), $y=104,5 \mathrm{~cm}$ (Dp- Pants length); Tailoring part's name: 1-OK-PANTS;

1 to $3=23,5 \mathrm{~cm}$ (Ds), l. Copy offset, distance $=23,5 \mathrm{~cm}$;

3 to $4=7,5 \mathrm{~cm}(\mathrm{Vb})$, I. Copy offset, distance $=7,5 \mathrm{~cm}$;

2 to $5=47,5 \mathrm{~cm}, 1 / 2$ (from 2 to $3+7 \mathrm{~cm}$ ), I. per on line, half - beginning $=47,5 \mathrm{~cm}$;

- I. Clipping, delete the line excess on the knee;

4 to $621,5 \mathrm{~cm}(\mathrm{Spn})$, I. per on line, whole - beginning = $21,5 \mathrm{~cm}$;

- I. Clipping, delete the line excess across the belt line and saddle line;

- I. Split, in dot 6;

6 to $95 \mathrm{~cm}(1 / 20 \mathrm{Ob}+0,5 \mathrm{~cm})$, I. Split, beginning $=5 \mathrm{~cm}$;

- I. Combine merge, compound lines from 4 to 6 and 6 to 7 ;

4 to $101 / 2$ (4 to 7 ), I. Per 2 points - halh;

- I. Clipping, delete the line excess across the waist line and length;

- I. Split, in dot 13

13 to 14 and 13 to $15=8,5 \mathrm{~cm}$ (1/4 Ond), I. Split - beginning $=8,5 \mathrm{~cm}$;

4 to $14-$ I. 2 point line, connect the dots;

9 to 15 I. 2 point line, connect the dots;

- I. Split, in dot 16 and 17; 




Figure 4. Basic construction of the women's pants front

13 to 14 and 13 to $15=1 \mathrm{~cm}, I$. Split;

14 to 18 and 15 to 19 - I. 2 point line, connect the dots; 4 to 18 - I. 2 point curve, connect the dots and the shape curve line;

9 to $20=7,5 \mathrm{~cm}$, I. Split, from dot 7 down to the beginning $=7,5 \mathrm{~cm}$;

$6-I$. Split in dot 6 (from dot 4 to the right beginning $=23,5 \mathrm{~cm}$ ) 6 to $210,5 \mathrm{~cm}, I$. Split, beginning $=0.5 \mathrm{~cm}$;

- I. Split in dot 7;

7 to $22=1 \mathrm{~cm}, I$. Split - end $=1 \mathrm{~cm}$;

21 to 22 - I. 2 point line, connect the dots;

20 to $21-I .2$ point curve, connect the dots and the shape the curve line;

19 to $20-I .2$ point curve, shape the curve by step;

22 to $23=18,5 \mathrm{~cm}(1 / 4 \mathrm{Op}+2 \mathrm{~cm}$, placket $)$ l. Split - end

$=18,5 \mathrm{~cm}$

23 to $4-I$. 2 point curve - connect the dots and shape the curve of the side seam;

23 to $24=1.2$ point line $-\quad \mathrm{x}=0.3 \mathrm{~cm} \quad \mathrm{y}=1 \mathrm{~cm}$

22 to 24 - I. 2 point curve - connect the dots and shape the curve on the waist of the front part

Replacing lines

- I. Swap line - select the lines $23-24$ and $24-22$, then the perimeter line $22-23$.

From dot 11 straight up $1 \mathrm{~cm}, I$. Move single point $-\mathrm{x}=0$

$y=1 \mathrm{~cm}$

- I. Clipping - delete the excess line

- I. Add dart-opens the gusset in dot 11 distance $=10$ $\mathrm{cm}$ (gusset depth), input value $=2 \mathrm{~cm}$ (gusset width) .

Description of the back part of the pants

Basic construction of the back part of women's pants is shown in Figure 5.

The front part of the pants is the base for the construction of the back part.

14 to $25=2 \mathrm{~cm}$, I. Split - beginning $=2 \mathrm{~cm}$

15 to $26=2 \mathrm{~cm}$, I. Split - end $=2 \mathrm{~cm}$.

18 to $27=2 \mathrm{~cm}, I$. Split - beginning $=2 \mathrm{~cm}$.

19 to $28=2 \mathrm{~cm}, I$. Split - end $=2 \mathrm{~cm}$.

25 to $27-$ I. 2 point line - connect dots

26 to $28-$ I. 2 point line - connect dots

- I. Split in dot 10

10 to $29=1,5 \mathrm{~cm} \mathrm{I}$. Split - distance $=1,5 \mathrm{~cm}$

29 to $30=5,5 \mathrm{~cm}(1 / 20 \mathrm{Ob}+1 \mathrm{~cm}) \quad$ I. Split - distance $=$ $5,5 \mathrm{~cm}$

- I. Split - in dot 3

3 to $31=3 \mathrm{~cm} \quad l$. Split - distance $=3 \mathrm{~cm}$

31 to 30 - I. 2 point line - connect the dots

- I. Perp on line - draw the right angle on the line 31 30, from dot 30,

- I. Copy Offset - on the line 31-30, draw the line which passes through dot 4

- I. Move single point - from dot 4 to the left, distance $=5 \mathrm{~cm}$

32 to $33=23,5 \mathrm{~cm}$ (Szn) I. Split - beginning $=23,5 \mathrm{~cm}$

- I. Perp on line - draw the right angle from dot 1 to the left,

27 to $34-$ I. 2 point line - draw line that passes through dot 33

- I. Clipping - cuts the excess of the line

33 to 27 - I. 2 point line curve - connect the dots and shape part of curvature of the side seam

- I. Distanc e2pt- measure the distance from dot 29 to $33=18,03 \mathrm{~cm}$

29 to $35=18,03 \mathrm{~cm}-$ I. Split - beginning $=18,03 \mathrm{~cm}$;

35 to 28 - I. 2 point line, connect the dots;

28 to 36 - (Measure the distance from 19 to 20 of the front part) -0 to $1 \mathrm{~cm}$,

- I. Split

28 to $36=1$. 2 point curve - shape the curve of the back part of the step

- I. Distanc e2pt-measure the distance from dot 12 to 34 , measured distance is transferred from dot 12 to $37-$ distance $=59,88 \mathrm{~cm}$

12 to $37=59,88 \mathrm{~cm}$ i. 2 point line;

37 to 34 - I. 2 point line - connect the dots;

37 to $38=19,5$ (1/4 Op) I. Split - beginning $=19,5 \mathrm{~cm}$.

33 to 38 - I. 2 point curve - connect the dots and shape part of curvature of the back side seam. 


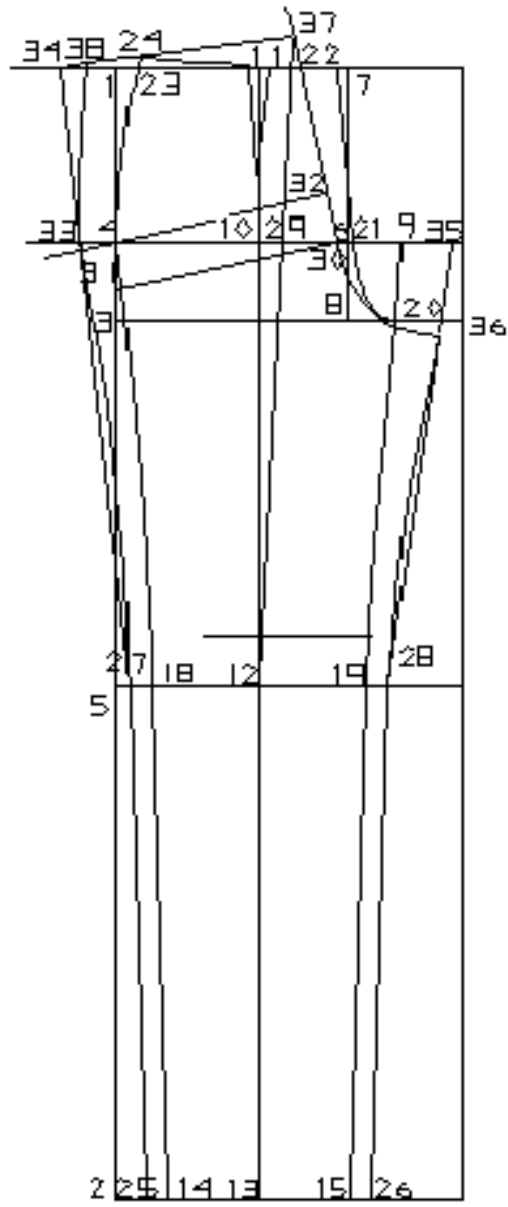

Figure 5. The basic construction of the women's pants rear

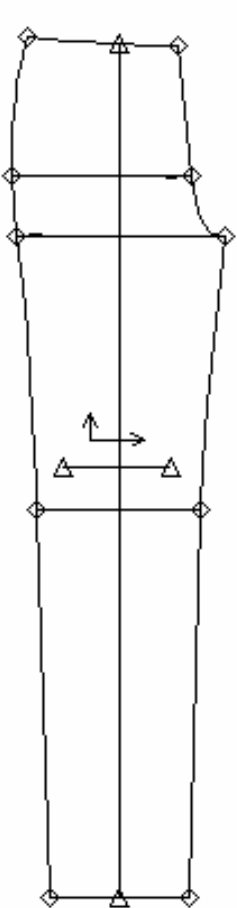

a)

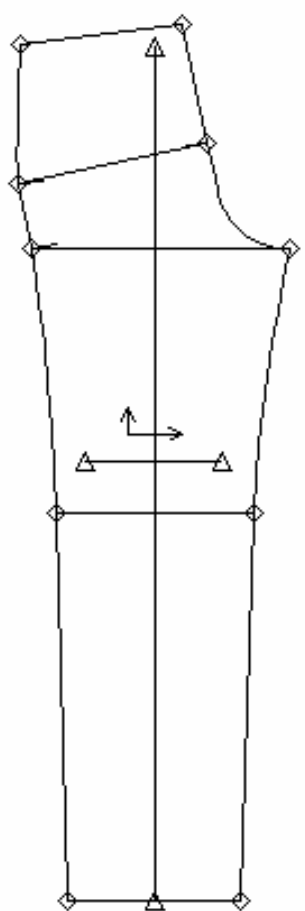

b)
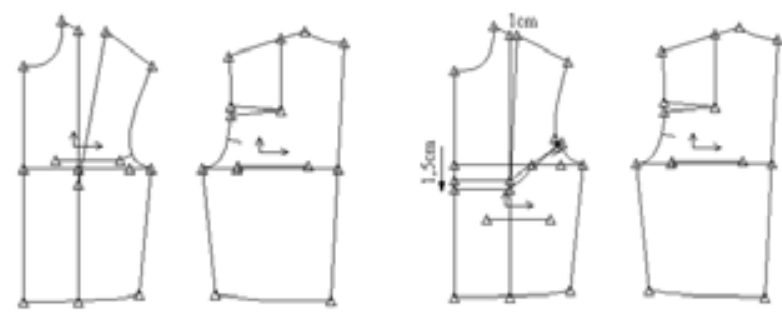

Figure 7. Women's blouse modelling preview

The modeling of the pants (Figure 8) was carried out according to the model design. On the line of the belt of front and back parts the narrowing is shown, deepening and widening in perches, narrowing on the line of knees of $4 \mathrm{~cm}$ in total on one trouser leg and $20 \mathrm{~cm}$ widening in total by the length.
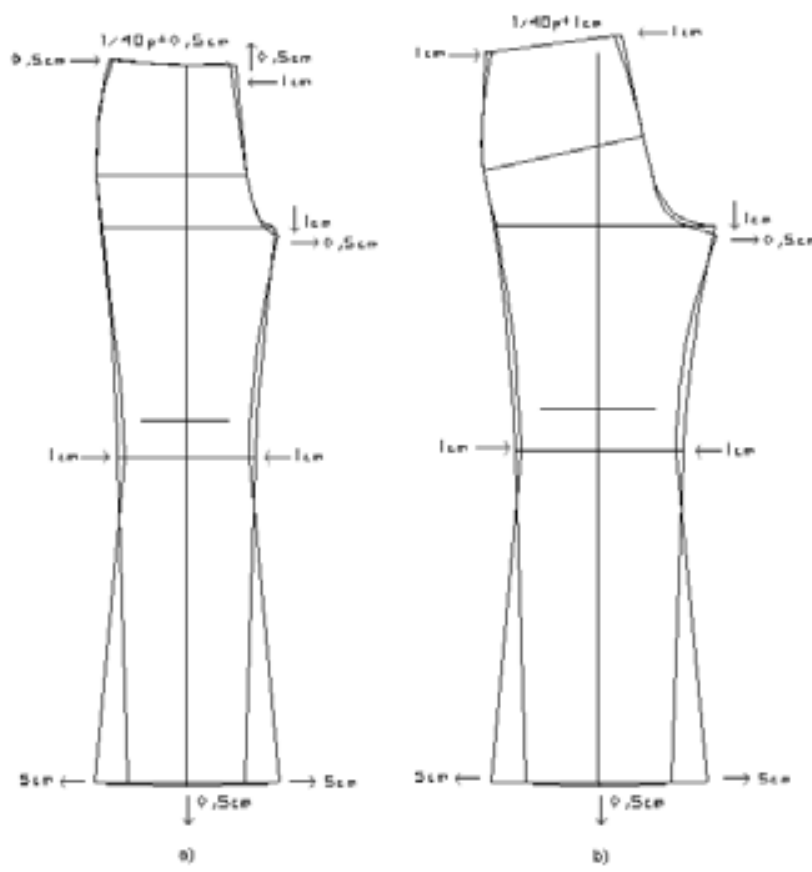

Figure 8. Women's pants modelling preview: a) front; b) back

Figure 6. Separete tailoring parts: a) front; b) back

The separation of front and back parts of women's 
Annexation of tailoring parts and modeling of the jumpsuit

After modeling of the tailoring parts of the blouse and pants, annexation has to be done or the connection of upper and lower parts for further modeling. In Figure 9 modeling of front and back parts according to a given design is shown.
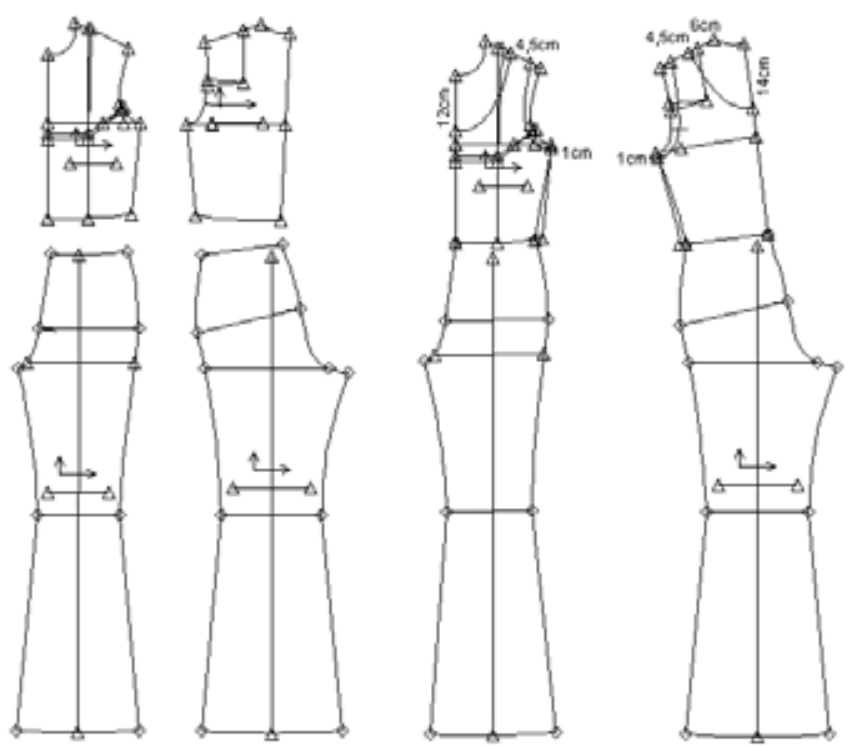

Figure 9. Women's suit binding and modelling

Display of tailoring parts of the jumpsuit

The separation of modeled tailoring parts is done with the tool Draft, by selecting the main and auxiliary lines.

A display of separated tailoring parts of women's jumpsuit is shown in Figure 10.
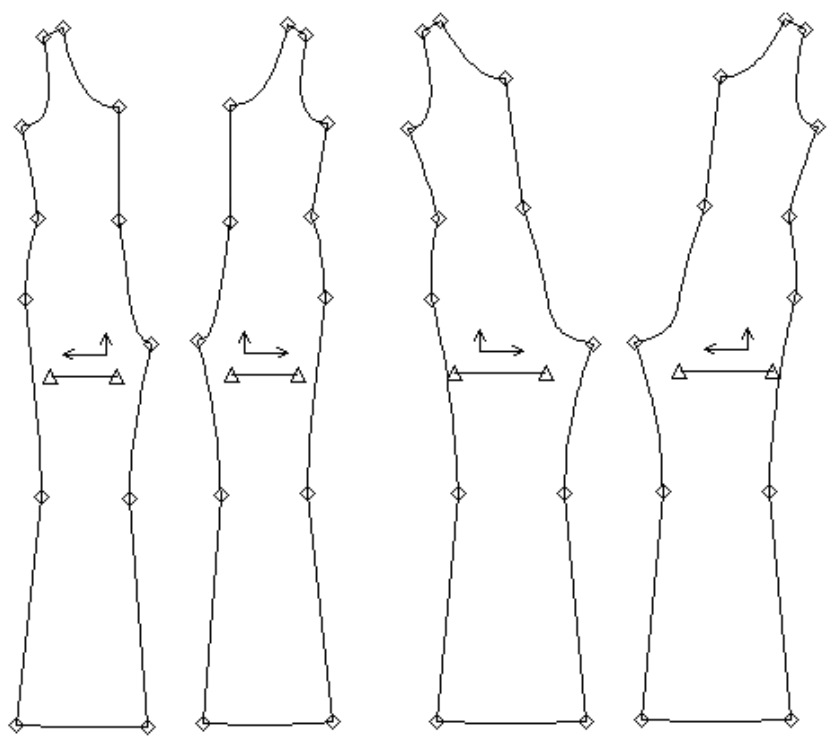

a)

b)

Figure 10. Women's suit tailoring parts: a) front; b) back

The simulation of women's jumpsuit coveralls

The simulation of women's jumpsuit coveralls is shown in 3D V-Stitcher program. The greatest advan- tage of 3D softer is virtual sewing of garments shown in Figure 11. Making a prototype is important for spotting and rectifying mistakes before starting the production of a garment.

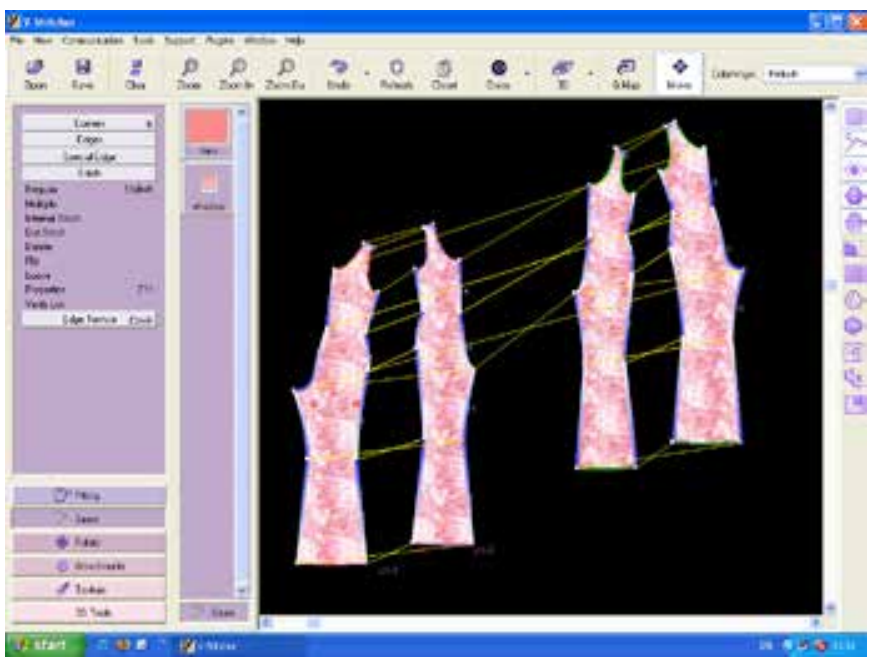

Figure 11. The preview of virtual sewing tailoring parts

The adjustment of anthropometric measures of a three-dimensional parametric model of the doll's body was done in the 3D system, according to the chosen size of a jumpsuit. On the base of prepared tailoring parts in PDS, the simulation of clothing, the women's jumpsuit, was done taking into account the properties of the fabric (Figure 12).

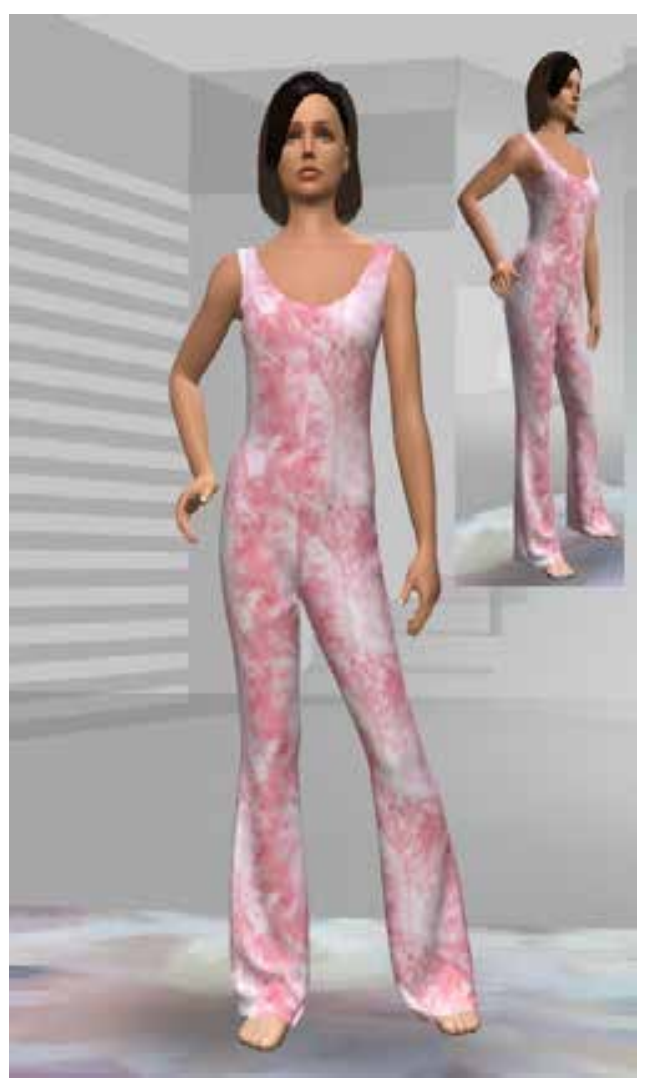

Figure 12. The preview of virtual clothing-women's suit 
Subjective visual evaluation of the computer simulation of women's jumpsuit shows overalls, adhesion, draping and achievement of 3D shapes.

This model shows extreme following of the line of the body, a gently shaped figure with fullness of the breasts and emphasized hips. [7,8]

\section{Conclusion}

AccuMark software allows forming of data bases which are the condition for using the new 3D technology which allows the control of shaping tailoring parts before the production of the garment.

Establishing the harmony between the shape of the model, a chosen fabric and the color gives the quality to the finished garment. It can be said that a good design of a garment conquers the market but the quality it keeps. New generations of textile fabrics should satisfy the needs of customers for greater comfort and a new style, something that can be seen in advance with the 3D technology.

The improved technology allows the view of the generated picture in movement, as well as the simulation of dynamic looks and wearing of the designer clothes. The software for making virtual clothes catalog, store editing, making data base of the garments etc. could also be used.

\section{References}

[1] AccuMark - professional edition GERBER Technology, June 2008.

[2] Script 3D Accumark V-Stitcher program, Gerber Technology, March 2007.

[3] D. Paunovic, G. Colovic "Construction of female clothes", Teagraf-Belgrade, Belgrade 1999.

[4] D. Ujevic, D. Rogale, M. Hrastinski: "Techniques of designing and modeling of clothes", University in Zagreb, Textile-Technical Faculty, Zagreb 2000.

[5] S. Antic, D. Radosavljevic, A. Ilic, Lj. Milenkovic, Manual for professional software usage for construction and grading on gerber system, Nis, 2013.

[6] Rundschau, Mode magazine, Munchen 5/2004

[7] Pavlinic D. Z., Gersak J., Evaluation of quality of clothing, Textil, 53 (10), 497-509, 2004.

[8] Pavlinic D.Z., Gersak J., The advanced method for the evaluation of garment appearance quality grade, Proceeding $f 7^{\text {th }}$ Annual textile Conference by AUTEX From Emerging Innovations of Global Business, 26-28 June 2007, Tampere, Finland, R. Salonen \& P. Heikkila, eds., CD Room, 1283

Izvod

\section{RAZVOJ UNIKATNOG MODELA ŽENSKOG KOMBINEZONA PRIMENOM 2D/3D CAD SISTEMA KONSTRUKCIJSKE PRIPREME ODEĆE}

Sladjana S. Antić, Ana B. Ilić, Dragana V. Radosavljević, Svetomir Z. Golubović

Visoka strukovna škola za tekstil, Leskovac, Srbija

Korišćenjem savremenih računarskih sistema rešavaju se problemi sa kojima se danas susreću proizvođači odeće kao česta promena modela odevnih predmeta po modnim sezonama i zahtevi za brzim izlaskom na tržište. U ovom radu na bazi osnovne konstrukcije ženskog kombinezona izvršeno je modelovanje i ceo pstupak izrade 2D kroja primenom 2D/3D CAD sistema konstrukcijske pripreme odeće. Virtualna simulacija izvedena je na osnovu izabranog tekstilnog materijala uzimajući u obzir dezen i svojstva date tkanine. Definisani su svi potrebni parametri za realizaciju simulacije i analizom rezultata izvršena je provera modelovanih krojnih delova.
(STRUČNI RAD)

UDK 687.12:677.011

Ključne reči: osnovna konstrukcija, modelovanje, 2D krojevi i 3D simulacija 